reader wanting information about the separation of serum proteins on ion exchange celluloses, or about the separa. tion of amino-acid, sugar and steroid derivatives on gas chromatograms, or about technical developments in gas chromatography in the past five years, will need to refer to sources outside this book. To make matters worse, valuable space is devoted to a number of methods like the separation of amino-acids and proteins on partition columns, separation of proteins on ion exchange resins and preparative paper chromatography which have largely been superseded. This lack of balance is also reflected in the absence of critical evaluation in descriptions of many of the methods, and far too frequently passages about applications are little more than indiscriminate lists of references. Some topics are reasonably well covered, for example, paper chromatography, ion exchange, chromatography of amino-acids, thin-layer and mechanization. There are many practical tips and ample illustrations and tables. The literature is covered fairly thoroughly up to about 1961 .

That the days of the single general book on chromatography are probably numbered must be clear from a glance at the two volumes of Advances in Chromatography. These contain articles which range far and wide, from highly theoretical expositions of particular processes to descriptions of very sophisticated apparatus. It is not clear why in both volumes, and presumably in others to come, gas chromatography has a special section occupying half the space while all other forms of chromatography are lumped together in a general section. Some of the articles cannot be regarded as strictly appropriate under the heading of "Advances". Nevertheless, they are worth including if they provide historical background or suggest possible fields of application. Thus, N. Pelick, H. R. Bollinger and H. K. Mangold in Volume 3 give an instructive account about the development of thin-layer chromatography and provide translations of historically interesting papers not readily available to English readers. Also, A. G. Ritchie, in his first article in Volume 2, preaches the chromatographic gospel to geologists and claims in his second in Volume 3 that geological processes themselves are often chromatographic, though most geologists do not realize it. Space does not permit more than a brief mention of the remaining contents of these volumes. All the articles are interesting and well written; some are outstanding. While some articles throw new light on traditional stationary phases and processes, others deal with the very latest developments. If these volumes are anything to judge by, this series promises to be of major mportance for users of chromatographic methods.

I feel, however, that the books are too expensive.

R. CONSDEN

\section{NO ROOM FOR LUDDITES}

\section{Induction Machines for Special Purposes}

By. E. R. Laithwaite. (Newnes International Monographs on Electrical Engineering and Electronics.) Pp. xiii + $337+4$ plates. (London: George Newnes, Ltd., 1966.) 84s. net.

There was a time when general interest in electrical machines was waning. The principles of all the usual types were well known, and the experienced machines man knew, or thought he knew, all the answers. This state of affairs had two bad effects. The first was that the impression was given that all was known and the few problems left in the field were rapidly being cleared up. The second, which was perhaps more serious, was that teaching about machines was directed at the few types of commercial interest, the teaching emphasis being more on the ability to predict the behaviour by set methods, rather than a truly basic understanding of why the machines worked at all. Professor Laithwaite has spent many years on the development of an entirely new range of machines, and this new book goes a long way towards explaining clearly how these new induction machines work and how their characteristics can be predicted. Some of the work in the book has appeared elsewhere in the specialist journals, but a great deal of it is new.

The book opens with an introduction to linear machines and a thought-provoking chapter on equivalent circuits, a comparison of "constant voltage" and "constant current" systems, and the "goodness" factor which deserves to be better known.

Possibly Professor Laithwaite is best known to the general public for his appearances on television in connexion with high speed traction. This is a field in which there is a very lively interest, and a chapter is devoted to the practical and theoretical problems involved. Other chapters are concerned with linear machines for low speed and standstill applications, actuators, liquid metal pumps and conveyor belts. The emphasis here is not on efficiency but rather on the criterion "does the machine chosen do a better job than any other machine could do ?"

Then the author deals with self-oscillating motors, levitation by induction, induction machines as accelerators; medium speed applications, and variable speed motors, including the log-motor and the spherical motor. The book finishes with a section on two-phase servo-motors and a.c. tachometers.

Typical of Professor Laithwaite's approach to the subject is his ingenious use of equivalent circuits conforming with the physical conditions of the problem, rather than representing identically their mathematical expression. A very readable style is maintained throughout with the mathematics easily within the reach of most engineers.

This book will be welcomed by all who are interested in electrical machines, and will take its place as a standard work of reference on the subject. E. M. Freeman

\section{FLOW OF AIR}

The Measurement of Air Flow

By E. Ower and R. C. Pankhurst. Fourth edition, completely revised. Pp. viii +367 . (Oxford, London and New York: Pergamon Press, Ltd., 1966.) 65s. net.

For the past thirty years the three earlier editions of this book have been widely recommended to all those concerned with the measurement of air flow. Dr. Pankhurst has joined Mr. Ower in this new edition which has been completely revised with more than 150 additional references and includes a comprehensive review of nearly every aspect of this work up to 1965 .

Starting with a general introduction and the principles of the pressure tube anemometer, the following chapters on pitot and static tubes introduce the work which will probably form the basis for the revision of the only outstanding section of B.S. 1042: 1943. The authors have been careful to refer the reader to the revised B.S. 1042: Part 1: 1964 (Methods for the Measurement of Fluid Flow in Pipes) in the chapter on the plate orifice, nozzle and venturi tube which obviously cannot cover the entire standard, but for flow at low Reynolds numbers the conical entrance orifice plate has a somewhat lower range of application than the other types mentioned. Care should be exercised in consulting the European work cited as references because the discharge coefficient $\alpha$ in the European work usually includes the factor $\left(1-m^{2}\right)^{1 / 2}$, where $m$ is the ratio of the orifice area to the pipe area. Most British and American authors use the symbol $C$ or $C_{a}$ for the discharge coefficient when it is derived, as Ower and Pankhurst derive their $\alpha$ with this factor written as a separate term. The European $\alpha$ should be multiplied by $\left(1-m^{2}\right)^{1 / 2}$ to obtain the British (and Ower and Pankhurst's) equivalent. 